\title{
HISTORICAL AND TYPOLOGICAL CHARACTERIZATION OF CHURCHES IN THE HISTORICAL CENTRE OF CUSCO, PERU
}

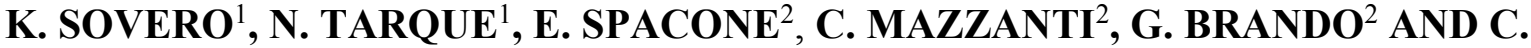 \\ ALFARO $^{3}$ \\ ${ }^{1}$ Pontificia Universidad Católica del Perú \\ Universitaria Av. 1801, San Miguel, Lima 32, Peru \\ e-mail: karim.sovero@pucp.edu.pe, sntarque@pucp.edu.pe \\ ${ }^{2}$ Università degli Studi "G. d'Annunzio" \\ Via dei Vestini,31, Chieti, Italy \\ e-mail: espacone@unich.it, claudio.mazzanti@unich.it, gbrando@unich.it \\ ${ }^{3}$ Universidad Andina del Cusco \\ Ingeniería Larapa Grande Urbanization, A-7 - San Jerónimo, Cusco, Peru \\ email: calfaro@uandina.edu.pe
}

Keywords: historical structure, masonry, failure mechanism, colonial churches

\begin{abstract}
UNESCO declared Cusco a historical site due to the importance of its constructions and traditions. However, Cusco lies on an active tectonic area with several plate faults and thus, is prone to endure seismic activity. The 1650 and 1950 earthquakes had devastating consequences on churches, with collapses of bell towers, roofs and vertical walls. After these earthquakes, the churches became more complex because of reinforcement and diverse structural changes introduced. Therefore, it is necessary to understand their current static and dynamic behaviour. In addition, it is fundamental to establish control measures to preserve churches and to guarantee safety of the hosted people, as well as to protect the artistic, architectural and cultural treasures they contain. The first step, however, is to survey the churches and to fully identify their structural features.
\end{abstract}

This article presents a description of the architectural and structural typologies of the churches in the historic centre of Cusco and its relation to the most common failure mechanisms experienced by churches during earthquakes. To this end, this research carefully recreates typologies, geometry, materials and interventions carried on over centuries on these churches. It contributes to the seismic vulnerability knowledge of the studied churches and gives conclusions for decision-makers in future resilience plans.

\section{INTRODUCTION}

Nowadays, Cusco is one of the most important UNESCO World Heritage sites in Latin America. Its historical centre still shows a valuable case of superposition of various historical phases. Among its main architectural expressions are religious buildings. After the $\mathrm{XVI}^{\text {th }}$ century Spaniards occupation of Cusco, the city's urban organization experienced some 
adaptation to European architectural standards. The new inhabitants occupied the most important areas and replaced ancient Inca structures with their buildings. The conquerors built their residences around parish churches while natives had to move to peripheral sub-urban areas, so-called barrios de Indios, which also expanded around smaller churches.

In order to establish their religious beliefs, Spaniards started immediately construction of valuable sacred architecture, often atop ancient Inca structures such as temple walls. This superimposition of Spaniards building techniques over Inca ones is still visible today in churches [1].

The arrival of Spaniards to America brought construction techniques already widespread in Europe at that time, such as arches and domes. In Peru, most churches had large naves that ended at the presbytery where baptistery, choir, and altar with sacristy and other accessory places on the sides were located. The material used for churches depended on their location. In some areas stones were mainly used (Figure 1a) rough-hewn or in square blocks joined with lime mortar. Alternatively, the material was adobe with mud mortar and mud plastering (Figure 1b). The Spaniards also introduced terracotta roof tiles but continued to use thatched roofs for smaller or temporary churches [2].
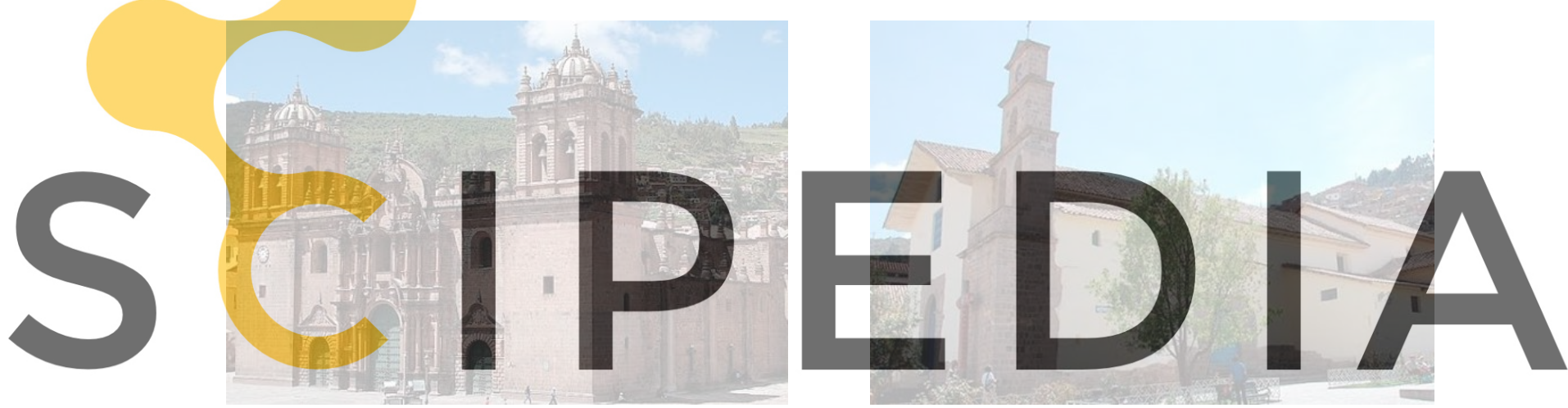

Register for free at https//www.scipedia.com to download the version without the watermark

Figure 1: Materials used in Cusco churches a) Stone with lime mortar in the Basilica de la Catedral and, b) Adobe with mud mortar in the Templo de San Blas.

The 1650 earthquake produced serious damage to many buildings, especially religious ones. Most of them were totally rebuilt or drastically modified until the end of the 17th century. These architectural features remained almost unchanged until 1950 when, following another major earthquake, all main churches in the city were restored. This restoration kept shapes identical but in some cases used different materials for reconstruction or consolidation [3]. A large-scale vulnerability evaluation was carried on in the centre of Cusco based on experiences learned from the L'Aquila earthquake. It took in account mainly adobe and stone masonry dwellings. The conclusion was that changes at the historical centre increased vulnerability of this important part of the city [4].

Nowadays, it is a fact that unreinforced masonry churches are more vulnerable to earthquakes. This is mainly due to their volumetric configuration and large dimensions of interior spaces. In addition, they have several potential sources of fragility problems such as inadequate connection between walls or absence of restraining elements, buttresses or similar, to help support vertical and horizontal loads from sub-horizontal structures (roof) [5]. Churches 
analysis is complex due to their architectural configuration and the difficulty in material characterization because of its non-linear behavior and low tensile strength. In this type of buildings, it is possible to identify multiple macro elements as main façade, sidewalls, columns, vaults, apse, transept, dome, and bell tower. Therefore, there are multiple potential failure mechanisms as compared to common masonry buildings [6].

This research describes the main characteristics of Cusco churches and their historic, architectural and structural features, taking into account interventions made after earthquakes, with the purpose of understanding their seismic behaviour. The International Council of Monuments and Sites (ICOMOS) established a series of steps to diagnose and implement interventions in structures considered as cultural heritage. These steps are: (a) data acquisition, to obtain basic information about main characteristics of the building; (b) historical, structural and architectural research; (c) structure survey and (d) field research, laboratory tests and monitoring. Natural causes expose cultural heritage to deterioration and even to socio-economic phenomena deriving from society evolution. ICOMOS indicates that it is mandatory for governments to identify, protect, conserve, rehabilitate and transmit cultural and natural heritage to future generations. As part of this, the development of scientific and technical studies as well as research is needed to improve intervention methods on monumental heritage.

\section{2}

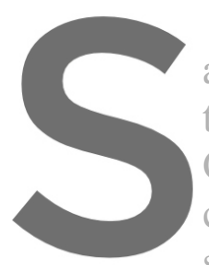

In Cusco there are

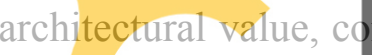

two symmetrical bell to

Churches plan view ha

configuration [1]. Figur

shows their geographictocalization. Four of then
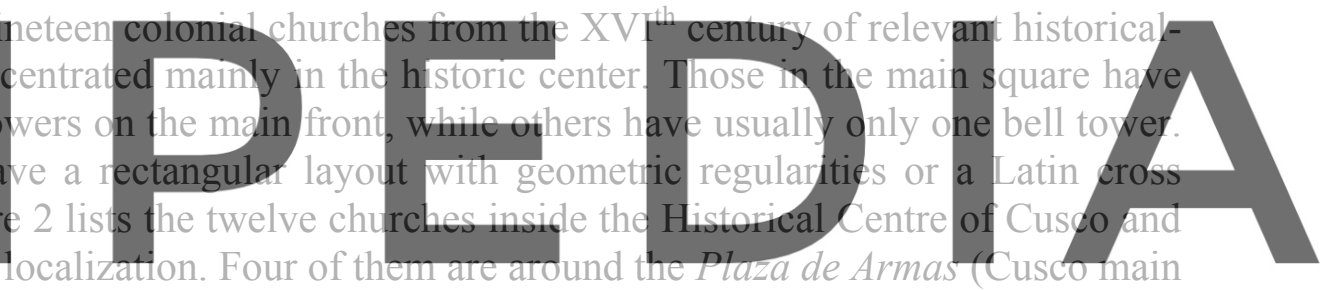

square) and the others are at the perimeter of the area.

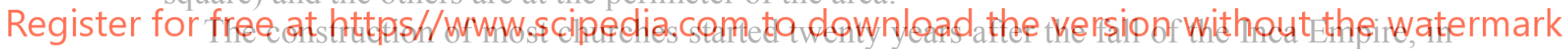

1531. In most cases, materials came from the destruction of Inca temples. The 1650 earthquake

destroyed most structures, which were rebuitt in a different style. Table 1 presents the construction year of each church, as well as some useful information such as construction material, plan view shape and number of towers or bell gables.

The former National Institute of Culture [8], now Ministry of Culture of Peru, declared all the historic buildings described in this article as Cultural Heritage on December 28, 1972. 

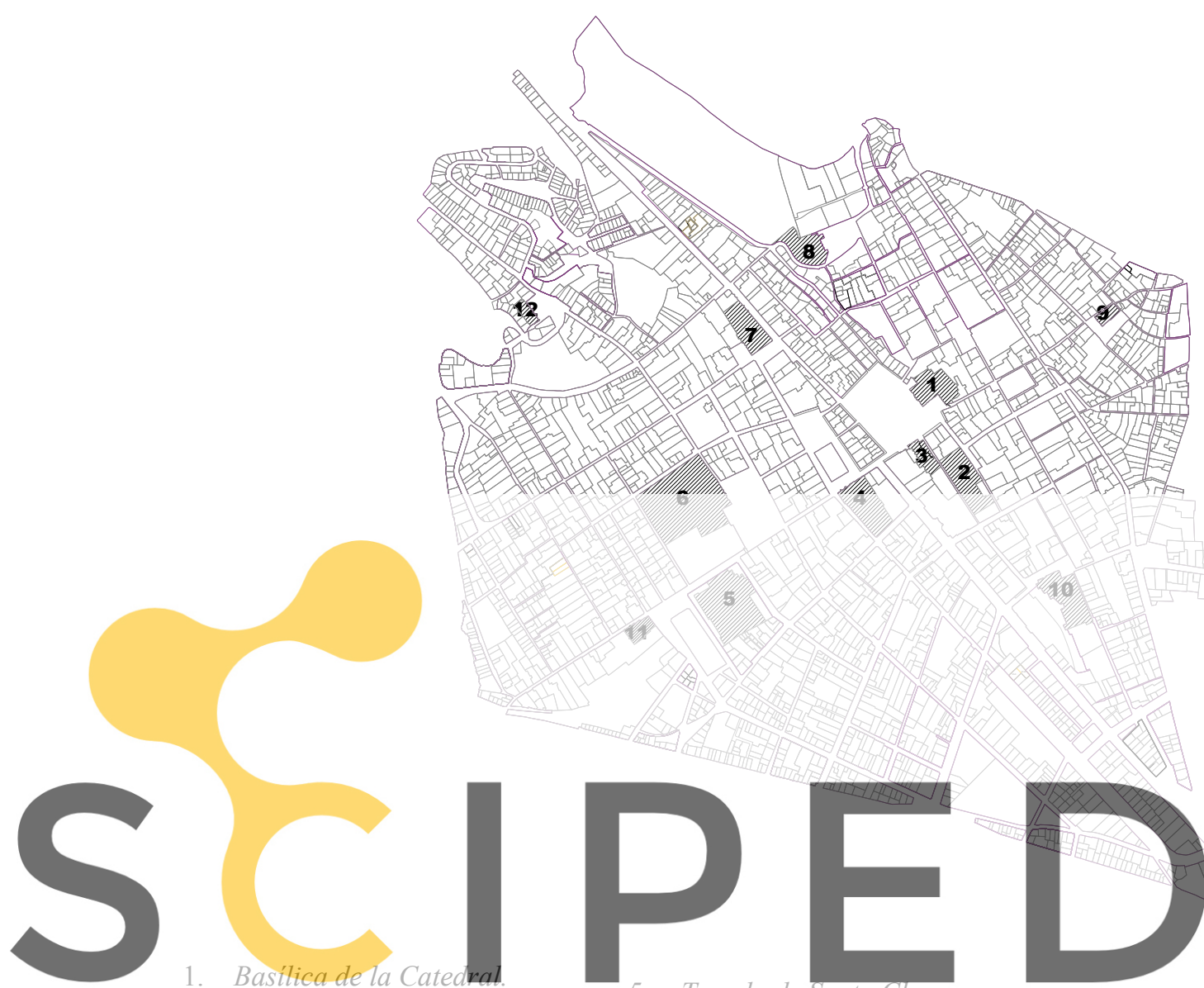

1. Basitica de la Catedral

2. Iglesia de Santa Catalina de

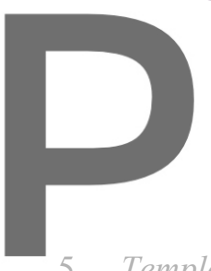

5. Templo de Santa Clara

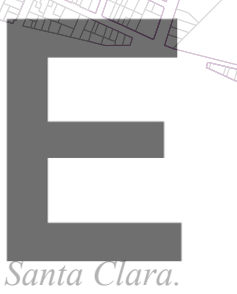

co de

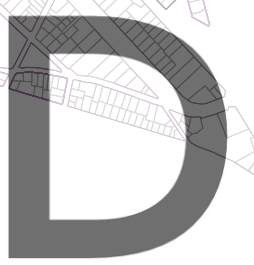

9. Templo de San Blas.

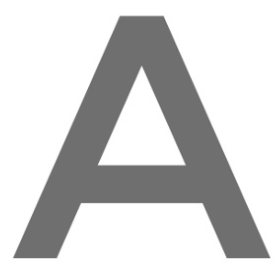

enatermark

4. Basilica Menor de La Merced.

7. Templo de Santa Teresa.

8. Iglesia de San Cristóbal.

12. Iglesia de Santa Ana.

Figure 2: Location of the basilicas, churches, and temples in the Historic Centre of Cusco [7].

Table 1: Main characteristics of Cusco churches

\begin{tabular}{|c|c|c|c|c|c|}
\hline Church & $\begin{array}{c}\text { Construction } \\
\text { year }\end{array}$ & $\begin{array}{c}\text { Plan view } \\
\text { shape }\end{array}$ & Main material & $\begin{array}{l}\text { Number of } \\
\text { bell towers }\end{array}$ & $\begin{array}{l}\text { Number of } \\
\text { bell gables }\end{array}$ \\
\hline 1. Basílica de la Catedral. & $\begin{array}{c}1560 \\
1650-1654\end{array}$ & Rectangular & Carved stone & 02 & -- \\
\hline $\begin{array}{l}\text { 2. Iglesia de Santa Catalina } \\
\text { de Sena. }\end{array}$ & $\begin{array}{l}\text { Before } 1650, \\
1669\end{array}$ & Rectangular & Carved stone & 01 & 01 \\
\hline $\begin{array}{l}\text { 3. Iglesia de la Compañia } \\
\text { de Jesús. }\end{array}$ & $\begin{array}{c}\text { Before } 1650 \\
1651-1668 \\
\end{array}$ & Latin cross & Carved stone & 02 & -- \\
\hline $\begin{array}{ll}\text { 4. } & \text { Basílica menor de La } \\
\text { Merced }\end{array}$ & $1650-1657$ & Latin cross & $\begin{array}{c}\text { Rounded } \\
\text { stone }\end{array}$ & 01 & -- \\
\hline 5. Templo de Santa Clara. & 1622 & One-nave & $\begin{array}{l}\text { Rounded and } \\
\text { carved stone }\end{array}$ & 01 & -- \\
\hline
\end{tabular}


Sovero et al.

Table 1 (continuation): Main characteristics of Cusco churches

\begin{tabular}{|c|c|c|c|c|c|}
\hline Church & $\begin{array}{c}\text { Construction } \\
\text { year }\end{array}$ & $\begin{array}{l}\text { Plan view } \\
\text { shape }\end{array}$ & Main material & $\begin{array}{l}\text { Number of } \\
\text { bell towers }\end{array}$ & $\begin{array}{l}\text { Number of } \\
\text { bell gables }\end{array}$ \\
\hline $\begin{array}{l}\text { 6. Iglesia de San Francisco } \\
\text { de Asis. }\end{array}$ & $1549-1652$ & Latin cross & $\begin{array}{l}\text { Rounded and } \\
\text { carved stone }\end{array}$ & 01 & -- \\
\hline 7. Templo de Santa Teresa. & $1673-1676$ & One-nave & $\begin{array}{c}\text { Rounded } \\
\text { stone }\end{array}$ & -- & 01 \\
\hline 8. Iglesia de San Cristóbal. & 1546 & Latin cross & $\begin{array}{c}\text { Adobe and } \\
\text { carved stone }\end{array}$ & 01 & -- \\
\hline 9. Templo de San Blas. & 1559 & One-nave & $\begin{array}{l}\text { Adobe and } \\
\text { carved stone }\end{array}$ & -- & 01 \\
\hline $\begin{array}{l}\text { 10. Iglesia de Santo } \\
\text { Domingo. }\end{array}$ & $\begin{array}{c}1633 \\
1650-1680 \\
\end{array}$ & Latin cross & Carved stone & 01 & -- \\
\hline 11. Iglesia de San Pedro. & $\begin{array}{c}1556 \\
1650-1657 \\
1688\end{array}$ & Latin cross & $\begin{array}{l}\text { Rounded } \\
\text { stone }\end{array}$ & 02 & -- \\
\hline 12. Iglesia de Santa Ana. & 1560 & One-nave & $\begin{array}{l}\text { Adobe and } \\
\text { rounded stone }\end{array}$ & -- & -- \\
\hline
\end{tabular}

\subsection{Description of the churches in Cusco}

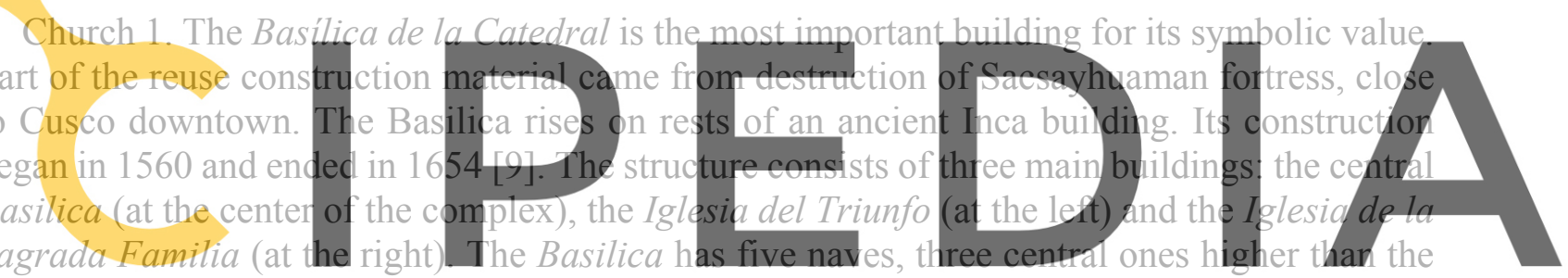

two lateral ones; the roof consists of twenty-one vaults supported by fourteen columns, twenty-

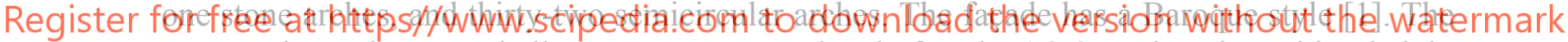
two quadrangular stone bell towers were completed after the 1650 earthquake, with a height lower than the one of the initial project.

Church 2. The Iglesia de Santa Catalina de Sena, located 100 meters from the cathedral, was rebuilt after the 1650 earthquake. It was probably completed in 1669 but was already in use since 1653. The new walls rest on an embankment formed by the fall of the ancient building stonewalls [10]. The church has a single rectangular nave [1] covered with cross vaults and a dome. Around the church are two cloisters, the main one with stone and brick galleries and the other one with adobe. From there, it is possible to observe twenty-nine niches that belonged to a wall of the Hunkunkancha, an important building from the Inca era. Currently, the monastery, besides being a religious center, has become a tourist museum.

Church 3. At Cusco main square, besides the Cathedral, there is also the Iglesia de la Compañía de Jesus. Before the Spanish conquest there was an important Inca architecture where this church stands. It became property of Hernando Pizarro (one of the Spanish conquerors), and was later demolished. Later on, the land was sold to the Jesuits who built a Church and a school; both were seriously damaged by the 1650 earthquake. Reconstruction began in 1651, starting from the chapel of the Virgen de Loreto. The new Iglesia de la Compañia de Jesús, with a Latin cross plan view, was completed in 1668 [10]. The symmetrical 
bell towers are the most interesting external architectural elements because of the indirect visual relationship with those analogous of the cathedral.

Church 4. Not far from the three churches already presented is the Basilica Menor de La Merced, facing Plaza Espinar. For construction of this church, Francisco Pizarro donated the land to the Orden de La Merced (Mercedarian Order), who began construction in 1535. In the beginning, it was a very simple church, in adobe with trusses of the type called "par y nudillo" (sort of reticular two-beam truss with horizontal stiffening element). The 1650 earthquake devastated the first building; that year the new construction began and lasted around seven years. In 1680, construction of a second cloister and the bell tower began [1]. This church has a Latin cross plan view with three naves; the central nave with a vaulted roof is wider and taller than the lateral ones.

Church 5. The Templo de Santa Clara is $500 \mathrm{~m}$ from the Plaza de Armas. Its construction began in 1599; this first building was replaced by the current one-nave building together with the monastery, both completed in 1622 [1].

Church 6. The construction of the Iglesia de San Francisco de Asis, located at the square of the same name, began in 1549 and ended in 1652. The delay was due to the devastation caused by the 1650 earthquake. The church has a Latin cross configuration with three naves; the central one is higher than the lateral ones.

Church 7. One block from the Plaza de Armas is located the Templo de Santa Teresa, in front of the square of the same name. Captain Don Antonio de Zea and his wife Doña María Urrutia donated the land to the Orden de los Carmelitas (Carmelite Order) in 1673, but its In addition, it has two bell gables with three columns each. At the facade, it is possible to
observe openings with round arches, where is located the corner balcony yebuilt over Inca yals
[1].
Church 8. The Iglesia de San Cristóbal is close to Cusco main square. Built in 1546, in 1560

it became a parish reserved for Indians. The plan view presents a Latin cross scheme with a

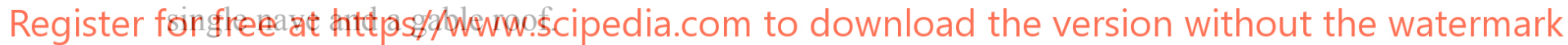
Church 9. Another building initially reserved for Indians is the Templo de San Blas, one of the first five temples built following a special evangelization request from Viceroy Andrés Hurtado de Mendoza in 1559. The church consists of a single nave, with two access portals, one overlooking the San Blas square and the other facing the main front. On the right side of the main façade is a bell tower built in stone masonry with semicircular arch openings.

Church 10. The Iglesia de Santo Domingo, located in the homonym square, was built over remains of the Templo del Sol (Qorikancha), area which was assigned to Pizarro's brothers. Juan Pizarro donated the land to Fray Vicente Valverde, who belonged to the Dominican order. Transformation of the Inca temple into a Catholic church took place in 1633, but the original building suffered serious damage with the 1650 earthquake. Reconstruction of the church was completed in 1680 .

Church 11. The Iglesia de San Pedro was built by the architect Juan Tomás Tuyrutupa. It is located six blocks from Cusco main square. This church has a Latin cross shape in plan view with two bell towers made of carved stone. This building has a main central nave with chapels at each side. The roof consists of five vaults over the main nave, two above the transepts and one over the baptistery. Its façade is baroque, three bodies in height. 
Church 12. The Iglesia de Santa Ana was constructed as a church for town people, so its structure was very simple. The 1650 earthquake did not produce much damage to it. The structure has rectangular shape plan view, with a single nave. The roof is simple, made of wooden structure with triangular shape and colonial tile coverage.

The characteristics of most churches are a Latin cross plan view with one central dome (Figure 3a). Furthermore, almost all façades are two or three bodies in height (Figure 3b) with baroque pilasters close to the main entrance. In addition, they have at least one or two towers with round arches or bell gables (Figure 3c).
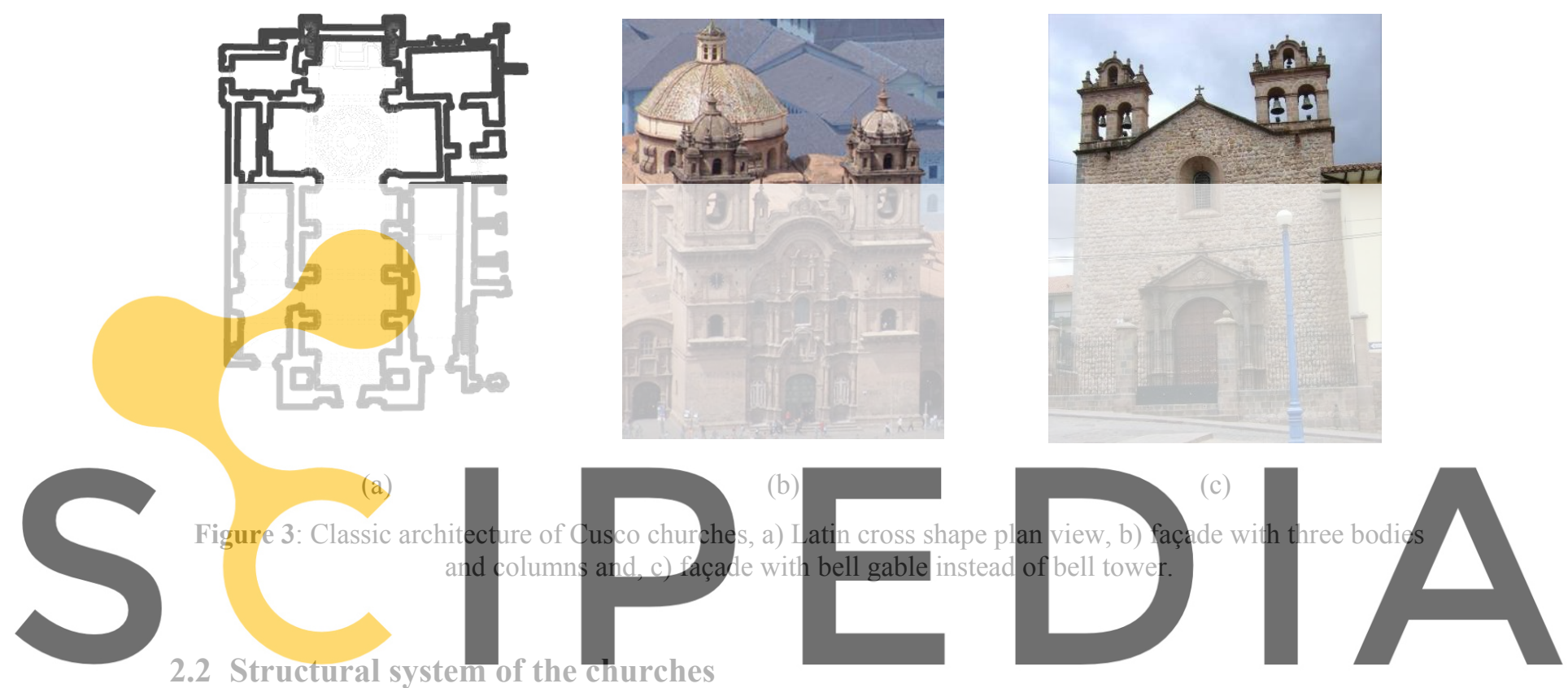

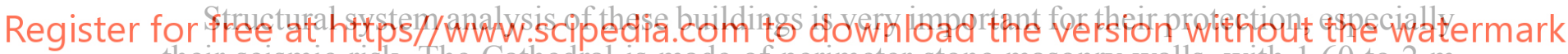
their seismic risk. The Cathedral is made of perimeter stone masonry walls, with 1.60 to $2 \mathrm{~m}$ thickness. There is no information about another material inside the walls. Columns are externally made of stones and internally have a filler material; together with arches, they support the roof system (vaults). The stone used is granite and is mainly obtained from the Sacsayhuaman fortress. Both Iglesia de la Sagrada Familia and Iglesia del Triunfo constitute buttresses to the Basilica walls. The difference in height among the three buildings could increase seismic vulnerability of the central Basilica.

Other churches have structural characteristics similar to the Cathedral, with thicker walls (about $2 \mathrm{~m}$ ) formed by square stone blocks joined with lime mortar. The Iglesia de Santa Catalina de Sena has brickwork with non-rectangular blocks. The relatively regular configuration of this building would indicate that it has adequate seismic behavior. However, window openings are not aligned correctly and this makes the sidewalls areas weak.

The Basilica Menor de La Merced has two stone buttresses that strengthen the side façade. The second floor walls of the cloisters and the sacristy are of adobe bricks. The roof system of this church consists of vaults supported by arches and covered with light roofing bricks.

The Templo de Santa Clara has similar structural characteristics as the Basilica Menor de La Merced. Inside, arches are made of brick masonry and outside vaults are of bricks protected 
with handmade tiles. The plan view of the entire complex (church and cloister) is of irregular shape. The cloister walls are of adobe masonry, with a "par y nudillo" type roofing system and handmade tile covering [7].

Other churches are made of adobe. The Iglesia de San Cristóbal has mixed masonry with carved stone at the base and adobe walls at the top. Externally, walls have stone masonry buttresses. Inside, the roof is a wooden structure supported by five semicircular carved stone arches. A baptistery deposit and the sacristy are two small adobe buildings at the back façade. At the Templo de San Blas, the structural system is adobe masonry with stone cladding. Inside, the choir rests on a simple stone arch. Its roof system is "par y nudillo" type, covered with handmade tiles. Only the bell tower is completely stone structure.

As previously explained, the churches structural system consists of stone walls, adobe walls, or a combination of both. They are bearing walls that also support earthquake lateral loads. The condition of these walls may play an important role in their seismic vulnerability analyses. Some churches also have stone buttresses. The Cathedral has stone columns to support the roof system but in other churches stone or brick arches directly support them.

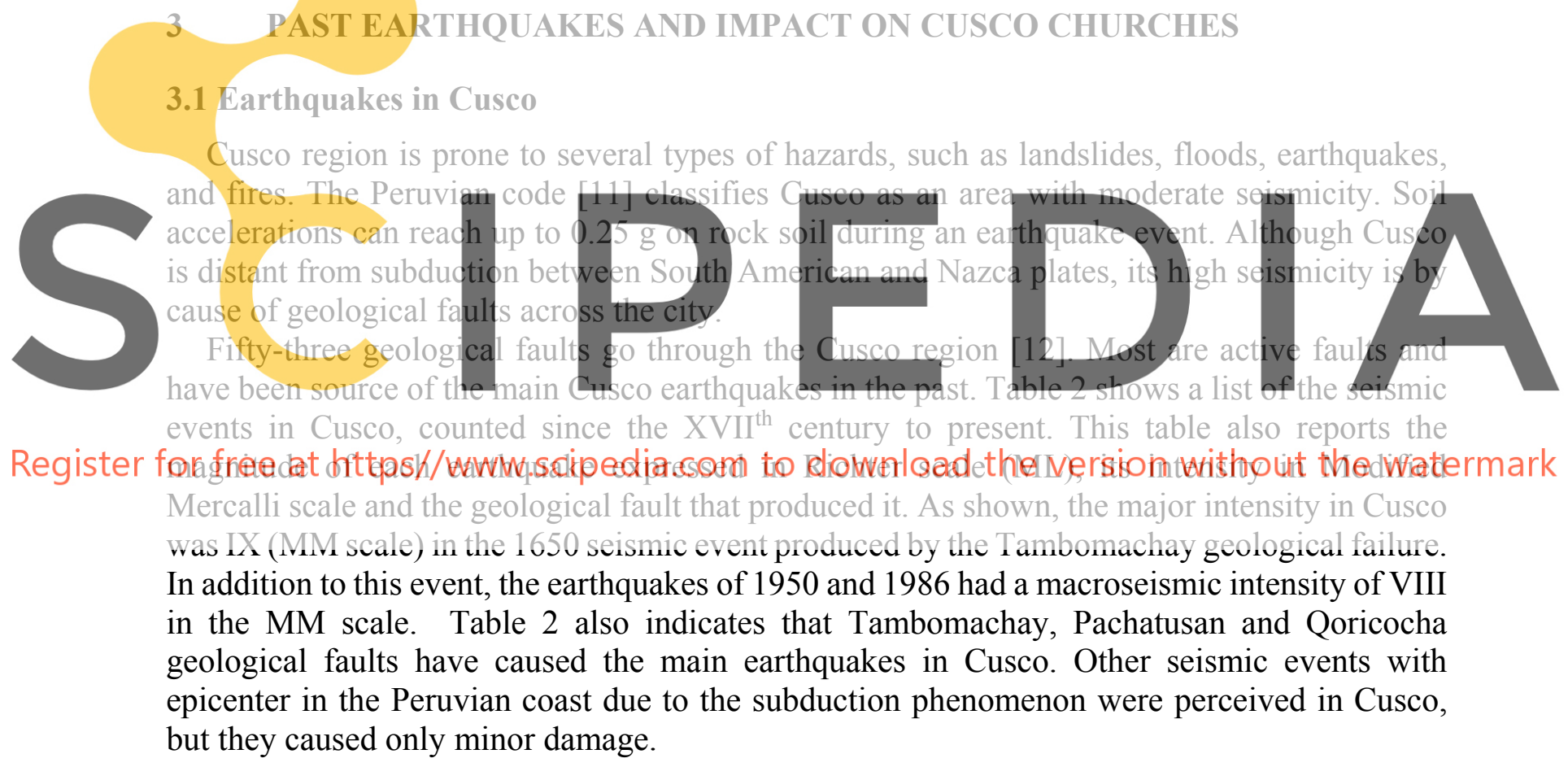

Table 2: List of earthquakes at the Cusco city since 1650 [12]

\begin{tabular}{ccccc}
\hline Date & Deep (km) & $\begin{array}{c}\text { Magnitude } \\
(\mathrm{ML})\end{array}$ & Intensity (MM) & Fault \\
\hline $31 / 03 / 1650^{*}$ & 30 & 7.2 & IX & F. Tambomachay \\
$19 / 11 / 1744^{*}$ & ---- & -- & VI & F. Tambomachay \\
$21 / 05 / 1950^{*}$ & 15 & 6.0 & VIII & F.Pachatusán \\
$03 / 06 / 1980$ & 20 & 5.0 & VI & F. Zurite-Huaracondo \\
$05 / 04 / 1986^{*}$ & 07 & 5.3 & VIII & F. Qoricocha
\end{tabular}




\begin{tabular}{ccccc}
$10 / 01 / 1998$ & 38 & 6.4 & V & ----- \\
$08 / 08 / 2003$ & 32 & 5.1 & V & F. Capacmarca \\
$28 / 09 / 2014$ & 06 & 5.1 & VII & Many \\
$2015-2019$ & $07-30$ & $3.2-4.4$ & II - IV & \\
\hline *Sismos que han afectado el Centro Histórico de Cusco & & &
\end{tabular}

\subsection{Damages in Cusco churches due to earthquakes}

The 1650 earthquake was one of the most destructive in Cusco. According to Chara and Caparó [1], several churches suffered serious damage and in most cases, some structures were demolished and rebuilt with other materials. Such is the case of the Iglesia de la Compañia de Jesús that originally was of adobe and after the earthquake was rebuilt with stone; also the Iglesia de Santa Catalina de Sena, where all Spaniard made walls were destroyed and only the Inca stone base did not suffer damage. Another example is the Iglesia de Santo Domingo that was totally destroyed.

After the 1650 earthquake, some constructions needed a change on their architecture. For example, the Basilica de la Catedral originally was designed with three towers but after the event, only two towers were built. Similar case is the Iglesia de San Francisco de Asís that remained with only one bell tower. On the other hand, some churches did not suffer damage, like the Templo de Santa Clara and the Templo de San Blas.

After the 1950 earthquake, according to Kubler [10], four churches needed restoration and two churches needed partial intervention. In addition, five churehes needed only minor repairs
and one needed demolition. The Basitica de la Catedral needed only partia intervention due to
little damage in the façade, in the arches and in the towers. The Iglesia de Santa Catalind de
Sena presented only some cracks in the transverse arches. In the Iglesia de la Compañja de
Jesús the central arch of the façade, the tower, and the central dome collapsed. The Templo
Santa Clara had only separation of perpendicular adobe walls.

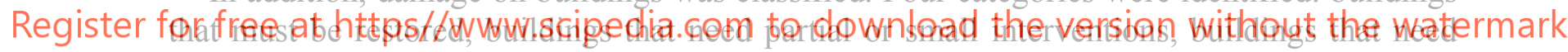
some major interventions, and buildings that must be replaced.

After the 1950 Cusco earthquake, six failure mechanisms were reported as the most common in churches [7]: at the façade top, aisle vaults, domes, apse overturning, bell tower fail, and bell gable fail (Figure 4).

As seen, churches may collapse partially or totally during earthquakes. In consequence, it is necessary to study and understand their seismic behaviour, and to propose fast and minimal interventions. 


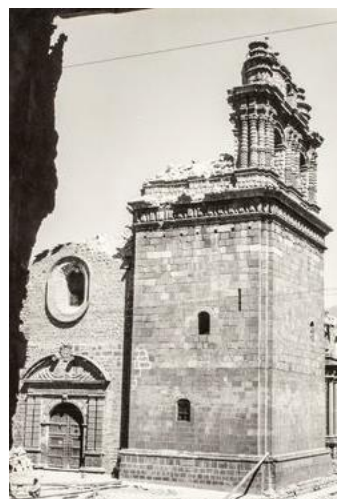

a) Mechanism at the top façade.

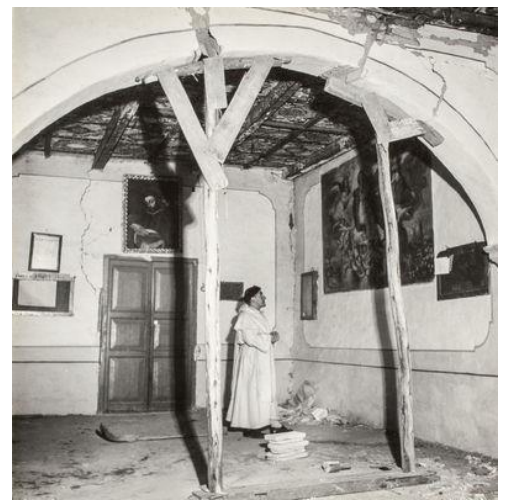

b) Aisle vaults

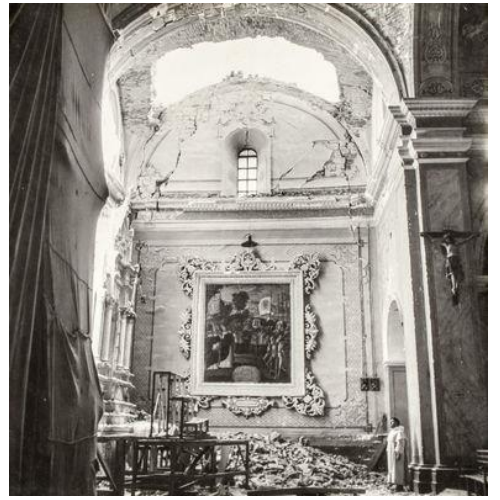

c) Dome.
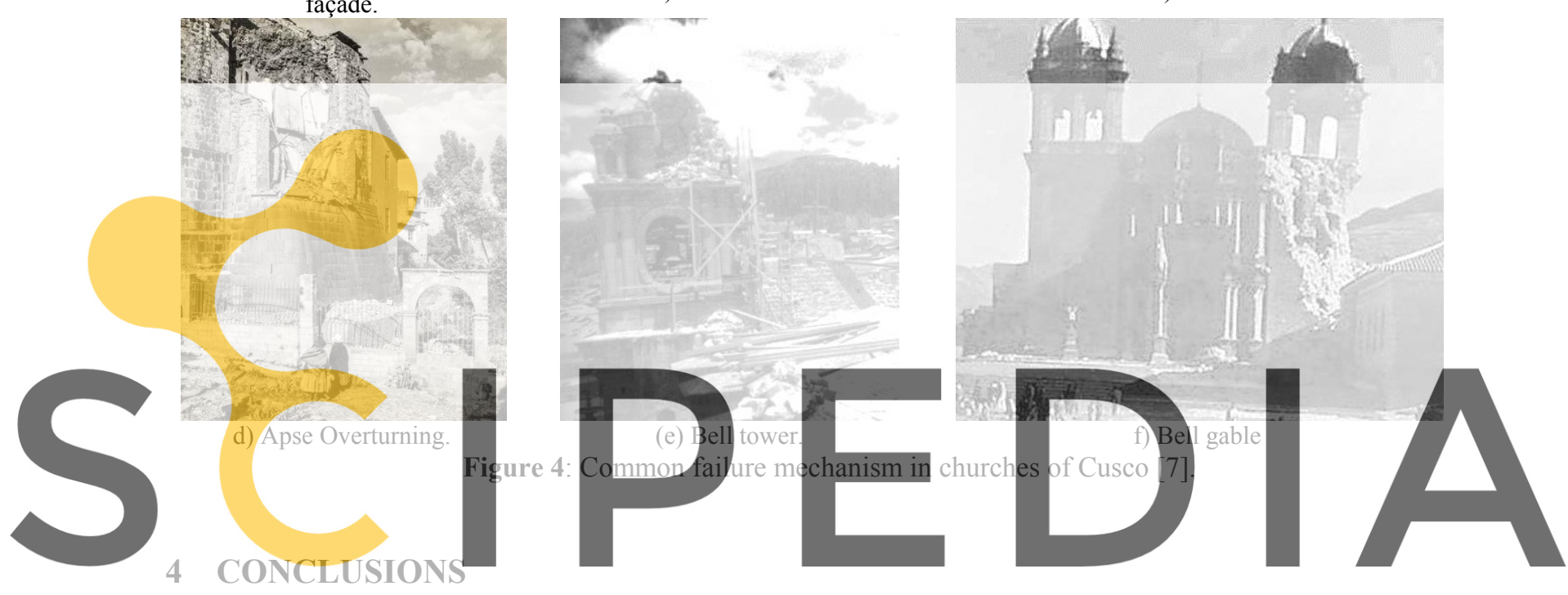

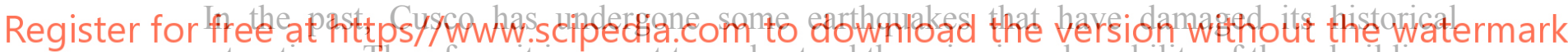
constructions. Therefore, it is urgent to understand the seismic vulnerability of these buildings in order to draw mitigation plans. This task should be done with simplified tools to cover the entire historical city and not only individual structures. Thus, large-scale methodologies could be useful for this purpose. This paper presents a historical and typological characterization of Cusco churches as a first step of a large-scale study. The main conclusions are as follows:

- In Cusco city there are nineteen colonial churches, but only twelve are inside the Historical Centre. Most of them were built before the 1650 earthquake. Nine of these churches were made with stone (carved or rounded). The other three (Templo de San Blas, Iglesia de San Cristóbal and Iglesia de Santa Ana) were made with adobe walls over a stone base. Furthermore, two of the colonial churches were built over Inca remains. This is the case of Iglesia de Santo Domingo built over the Templo del Sol, and Iglesia de Santa Catalina de Sena constructed over the Hatunkancha.

- It is possible to know the geometry of these buildings through chronicles and old paintings. The Latin cross shape with one nave and one bell tower or bell gable is common in the analyzed churches.

- $\quad$ Based on the same chronicles, it is possible to know the churches main material type. In most cases, masonry was made with stones (belonging to ancient Inca walls) and lime 
mortar.

- $\quad$ Since 1650, three big earthquakes had epicenters in Cusco city: earthquakes of 1650, 1950 and 1986 with intensities of IX, VIII and VIII in the MM scale respectively. Of them, the 1650 and 1950 events have had the most important consequences in the churches structures. However, only after the 1950 earthquake was it possible to identify the six most common failure mechanisms: at the façade top, aisle vaults, domes, apse overturning, bell tower fail and bell gable fail.

Acknowledgments. The authors thank all local authorities that helped collect important information and all Italian and Peruvian students who participated during data collection in Cusco.

\section{REFERENCES}

[1] Chara Zereceda, O., Caparò Gil, V. Iglesias del Cusco: historia y arquitectura, Editorial Universitaria UNSAAC, Cusco, (1998).

[2] Mendoza, R., Arquitectura religiosa en los Andes: apogeo, crisis y restauración. Universidad Mayor de San Marcos. Lima, Perú, (2016).

[3] Brando, G., Cocco, G., Mazzanti, C., Peruch, M., Spacone, E., Alfaro, C., Sovero, K., Tarque, N. Structural Survey and Empirical Seismic Vulnerability Assessment of Dwellings in the Historical Centre of Cusco, Peru. International Journal of Architectural Heritage (2019).

[4] Villegas, A; Estrada E. Centro histórico de Cusco, rehabilitación urbana y vivienda. Editorial Universitaria UNSAAC, Cusco, (1990).

[5] Mele E., Gatto, D., and De Luca, A. Structural analysis of basilica churches: A case study. Historical Constructions, P.B. Lourenço, P. Roca (Eds.), Guimarães, (2001).

[6] De Matteis G., Brando G., Corlino V. Predictive model for seismic vulnerability assessment of churches based on the 2009 L'Aquila earthquake, (2019).

[7] Municipalidad Provincial del Cusco. Plan Maestro del Centro Histórico de Cusco, (2018).

[8] Instituto Nacional de Cultura. Templos, Conventos y Cementerios declarados Patrimonio Cultural, (2000).

[9] Arzobispado de Cusco, Tesoros de la Catedral del Cusco, Dirección Desconcentrada de Cultura de Cusco, Telefónica del Perú - Gráfica Biblos, (2013).

[10] Kubler, G. Cusco. Reconstrucción de la ciudad y restauración de sus monumentos. UNESCO, (1951).

[11] Reglamento Nacional de Edificaciones del Perú. Norma Técnica de Edificaciones, NTE E.030, (2018).

[12] Benavente, C., Delgado F., Taipe E., Audin L. y, Pari, W. Instituto Geológico Minero y Metalúrgico del Perú. Boletín N55 Serie C. Geodinámica e Ingeniería Geológica, (2013). 